\title{
Palaeopathology of Findings among Archaeofaunal Remains of Small Seminar Site in Nitra
}

\author{
M. FABIŠ \\ Department of Animal Physiology, Slovak University of Agriculture in Nitra, \\ Slovak Republic \\ Received December 6, 2002 \\ Accepted February 11, 2004
}

\section{Abstract}

Fabiš M.: Palaeopathology of Findings among Archaeofaunal Remains of Small Seminar Site in Nitra. Acta Vet. Brno 2004, 73: 55-58.

The aim of this paper is to provide the information on pathologically altered elements of animal skeletons identified in archaeofaunal remains assemblage dated to the Iron Age period and collected during the rescue archaeological excavation in Nitra. In 1993, reconstruction work at Small Seminar uncovered an archaeological feature dating to the LaTène period (Iron Age). In addition to artifacts, animal remains represented by portions and fragments of skeletons were present. The remains were analyzed macroscopically. Only the sheep mandible was also examined using X-rays.

Skeletal elements of domesticated animals dominated $(98.5 \%)$ over the wild species elements $(1.5 \%)$. Five skeletal elements differed in shape and structure from their morphologic standards. Of the cattle skeletal remains, the affected elements are the phalanx proximalis and femur. Alteration of the phalanx almost certainly resulted from the exploitation of the animal in traction work. The caput femoris shows changes typical for coxarthrosis. One sheep mandible lacks the lower $\mathrm{P}_{2}$, a condition that is called oligodontia. Among the pig remains, we identified the following alterations: 1) Impressio laminae externae ossis frontalis into the sinus frontalis, 2) Abfractio laminae externae maxillae in the position of M1. Both lesions represent traumatic alterations. While the first happened around the time of death of the animal, the second one occurred clearly intra vitam.

The article widens the modest animal palaeopathology database, demonstrates a long history of skeletal alterations of animals, and, in the particular cases proves negative impact of humans on animals which were under their exploitation.

Bones, osteopathology, exostoses, arthrosis, oligodontia, fracturae

In the course of the reconstruction of Small Seminar in Nitra, an archaeological feature dating to the La Tène period (Iron Age) was discovered (Katkin 1995). In addition to artifacts, ecofacts represented primarily by archaeofaunal skeletal remains were unearthed. The animal bone assemblage contained not only "normal" skeletal elements but elements showing a certain degree of deviation in their morphology. The aim of this paper is to present the finds, provide their description, suggest diagnosis, identify (if possible) etiology, and enlarge an existing but very modest animal palaeopathology database.

\section{Materials and Methods}

The total amount of analyzed osteological material was small. The remains were fairly fragmented, which is generally characteristic of settlement waste. In such a context, almost only short or irregular bones usually keep their structural integrity, which is the situation with the finds presented in this paper. Only two samples were complete whereas the remaining specimens were broken to parts and/or fragments. Skeletal elements described in this article belonged to skeletons of the following domestic animals: cattle (phalanx proximalis, caput femoris); sheep (mandibula sinistra); and pig (os frontale sinistrum and maxilla dextra). All of the findings were studied macroscopically and the sheep mandible was also examined by X-ray apparatus. Additionally, each sample was photographed; some of these photographs are presented in this paper. The Small Seminar finds are stored at the Department of Animal Physiology of the Slovak University of Agriculture in Nitra.

\begin{tabular}{ll}
\hline Address for correspondence: & Phone: +421376018111 \\
MVDr. M. Fabǐs, PhD. & Fax: +421376411151 \\
Dept. of Animal Physiology, Slovak University of Agricultural in Nitra & E.mail: Marian.Fabis@ uniag.sk \\
Tr. A. Hlinku 2, 949 76 Nitra, Slovak Republic & http://www.vfu.cz/acta-vet/actavet.htm
\end{tabular}




\section{Results}

The archaeofaunal remains consist of 361samples. Skeletal elements of domesticated animals (98.5\%) highly dominate wild species remains (1,5\%) (Fabiš 2002). A portion of the analyzed bone assemblage was altered pathologically and/or developmentally. There are five such specimens, representing $1.4 \%$ of the entire analyzed bone assemblage. Pathological alterations of the cattle skeletal elements are as follows: 1) Phalanx proximalis of the III. or IV. finger of the thoracic limb (Plate X, Fig. 1) possesses exostoses close to the edge of the fovea articularis. The proximal joint surface is slightly enlarged in its dorsoabaxial angle. The joint surface of the trochlea is also enlarged and its dorsal part is lengthened in the proximal direction, spreading to some extent onto the corpus of the phalanx. The joint surface of the trochlea possesses a small, ovoid-shaped, highly polished area of sclerotisation/eburnation. There are three tiny openings within the eburnated area, penetrating the thin layer of subchondral compact bone. 2) The caput femoris is surrounded by exostoses on the edge of the joint surface (Plate X, Fig. 2). A fairly large part of the joint surface is highly polished and dense. Within this area the subchondral compact bone layer is very thin, occasionally even missing, which causes the underlying spongy tissue to be visible in these loci (Plate XI, Fig. 3). Changes in the sheep skeletal remains refer to the mandible (mandibula sinistra) where the lack of permanent $\mathrm{P}_{2}$ was recognized (Plate XI, Fig. 4). A juvenile pig frontal bone suffered from the break of the lamina externa ossis frontalis close to the processus zygomaticus ossis frontalis. A small part of the break is inserted into the frontal cavity (sinus paranasalis frontalis). The edges of the break are sharp (Plate XII, Fig. 5). The incomplete pig maxilla dextra shows a break from the lateral wall of the $\mathrm{M}^{1}$ alveolus. The edges of the break are not sharp but rounded (Plate XII, Fig. 6).

\section{Discussion}

Most of the changes described above represent results of chronic, hypertrophic pathological processes. Two of the examples resulted from traumatic injuries and one is a developmental anomaly. In the cattle phalanx proximalis, we detected both proliferative and degenerative processes influencing the "final" shape of the bone. The proliferative process resulted in creating exostoses of various size, shape and location. Thus, the original shape of the bone was significantly altered. In addition, changes affected surfaces of the joints. They resulted from proliferative (the enlarging of the edge of the joint surfaces) as well as degenerative (the distal joint surface) processes. The changes on the trochlea are diagnosed as osteoarthritis or arthrosis. Terminology of this condition is fairly wide (Š utta et al. 1986). This is basically a non-inflammatory degenerative alteration of a joint resulting in destruction of the joint cartilage, secondary alteration of the stripped subchondral compact bone, and deformation of the joint (Zendulka et al. 1987; and others). The exostoses develop as a consequence of a long-term irritation of the periosteum resulting in the periostitis chronica ossificans with bone (mostly local) proliferation. There are numerous factors that can cause periostitis of phalanges. Zendulka et al. (1987) suggest that hard work on rough terrain or a leg unconformity can predispose the animal to this condition. Both factors result in an overloading of the skeletal and muscular system that may locally (mainly in the location of ligament and tendon attachment) lead to inflammation with proliferative growth of new bone tissue. Consequently, this results in superficial roughness of various shape and size in the particular locations. B artosi ew ic z et al. (1997) describe pathological changes of the appendicular skeleton of cattle used in traction work in recent Romania. Studying the changes of the phalanx proximalis they recognized the following: 1) exostoses surrounding the proximal end (in $72 \%$ of the thoracic and $55 \%$ of the pelvic limb phalanges studied), 2) exostoses around the distal end (97\% of the thoracic and $86 \%$ of the pelvic limb 
phalanges), and 3 ) widening of the proximal articular surface (91\% of the thoracic and $77 \%$ of the pelvic limb phalanges). All samples having exostoses near the distal end of the phalanx also possessed widening of the trochlea on the dorsal side oriented proximally onto the corpus. Osteoarthritic changes of the trochlea were diagnosed only in one case and that was even the phalanx of the pelvic extremity. In order to distinguish stages of the pathological alteration, Bartosiewicz et al. (1997) proposed a classification scale ranging between 1 - 4 reflecting the development of the changes. According to the scale, the phalanx proximalis from Small Seminar belongs to Stage 3. Summarizing our finds and adopting the proposed classification, we can suggest that the described phalanx proximalis originates from an individual that most likely was exploited in traction work.

The second pathological find of cattle is the caput femoris. Similar to changes on the trochlea of the phalanx proximalis described above, we also found arthritic features on this sample. All identified changes are typical of the condition (Baker and B rothwell 1980; and others). However, when the hip joint is affected the condition is named coxarthrosis. Etiology of this condition is multifactorial and to assign only one unambiguous factor is impossible (Šutta et al. 1986). Nevertheless, we can again accept unconformity of the extremities or inadequate working exploitation on hard, rough terrain as contributing factors. Other possible reasons include an inflammation of the joint itself, followed by degenerative changes of the joint cartilage and subsequent alteration of the subchondral bone; a metabolic disorder; or a combination of these particular factors can cause the condition. A clinical symptom of coxarthrosis is a fairly significant limping on the affected limb, which would have certainly been easy for the ancient owner of the animal to recognize. The limp and decrease of the animal's efficiency might have been the crucial reason why just this individual (according to the state of the epiphyseal fusion, it was an adult animal) was slaughtered on the first appropriate occasion.

Regarding the sheep mandible, the lack of the permanent $\mathrm{P}_{2}$ represents a developmental anomaly known as oligodontia. X-ray examination proves that it is real oligodontia and not only retention of the tooth in the alveolus, for there is no tooth or tooth socket in front of the $\mathrm{P}_{3}$ in the alveolar bone. Thus far, we have not found any other examples of oligodontia in sheep mandibles among all previously analyzed archaeofaunal remains in Slovakia. Nevertheless, this condition is often recorded abroad. For example, it is described by Hoefs (1974 cit. in Miles and Grigson 1990) and Maltby (1997). Baker and Brothwell (1980) mentioned three finds lacking the $\mathrm{P}_{2}$ in the mandibles of small ruminants from United Kingdom; unfortunately from the text we cannot learn if the ruminants were sheep or goats.

The alteration of the frontal bone in the juvenile pig represents a traumatic injury. It is the incomplete fracture of the bone accompanied with an impression of the external lamina into the sinus frontalis (impressio laminae externae ossis frontalis). However, since we can see no healing processes remodelling the break, we assume that the break occurred near or very close to the time of death of this individual or perhaps shortly after. The pig's right maxilla suffered from a break out of the lateral wall of the $\mathrm{M}^{1}$ alveolus. The alteration was accompanied by loss of the tooth. The tooth was lost intra vitam, as the alveolus shows clear signs of resorption. The edges of the break are round without any sharp section. We diagnose this condition as the abfractio margo alveolaris $M^{l}$. It is an example of an incomplete fracture of traumatic origin.

To conclude: the finds discovered in Small Seminar in Nitra described in this paper illustrate cases of so-called "oral pathology" and pathology of the cranial and postcranial skeleton. In addition, there is one case of a developmental anomaly in this assemblage. Five of the 361 analyzed bone samples, or $1.4 \%$, showed some pathological alteration. These bones experienced hyperbiotic and hypobiotic processes that caused the particular changes in their morphology and structure. Description of the findings and their presentation to the 
general public brings the following benefits: 1) expansion of the modest animal palaeopathology database, 2) presentation of these particular conditions demonstrates a long history of skeletal alterations in animals, 3) some of the alterations can be identified as the result of intensive animal exploitation by ancient humans, which is strong evidence of the quality and intensity of human - animal interaction in the past as well as the negative influence of humans on animals kept and used under their control, 4) and lastly, we hope that the presentation of this interesting dimension of osteopathology will serve as a pleasant "refreshment" from the tedious daily routine of many practitioners and researchers in the fascinating field of veterinary medicine.

\section{Paleopatológia zvierat: nálezy medzi archeofaunálnymi zvyškami z malého semináru v Nitre}

Cielom príspevku je poskytnút informáciu o nálezoch patologicky pozmenených súčastí skeletov zvierat identifikovaných $\mathrm{v}$ súbore archeofaunálnych zvyškov datovaných do obdobia doby železnej a zhromaždených počas záchranného archeologického výskumu v Nitre. V roku 1993 počas rekonštrukčných prác na Malom seminári v Nitre bol odokrytý archeologický objekt datovaný do laténskeho obdobia (doba železná). Popri rôznych artefaktoch boli v objekte nájdené aj zvieracie zvyšky zastúpené častami a fragmentmi ich skeletov. Materiál bol analyzovaný na makroskopickej úrovni. V prípade dolnej čeluste ovce sme však využili aj Rtg prístroj.

Z hladiska početnosti vzoriek v súbore zvieracích zvyškov prevažovali domáce zvieratá $(98,5 \%)$ nad divo žijúcimi $(1,5 \%)$. Pät skeletových elementov sa odlišovalo v tvare a štruktúre od svojich morfologických štandardov. Medzi zvyškami hovädzieho dobytka to boli phalanx proximalis hrudníkovej končatiny a femur. Zmeny na prvom článku prsta takmer isto vznikli ako dôsledok využívania zvierata v tažnej práci. Caput femoris vykazoval zmeny typické pre coxartrhrosis. U mandibuly ovce sa vyskytla ologodoncia absentoval $\mathrm{P}_{2}$. U skeletových zvyškov ošípanej boli identifikované nasledovné poškodenia: 1) Impressio laminae externae ossis frontalis do sinus frontalis; 2) Abfractio laminae externae maxillae na úrovni $\mathrm{M}^{1}$. Obe lézie boli traumatického pôvodu. $\mathrm{K}$ prvej prišlo v čase blízkom smrti jedinca, druhá sa odohrala ešte počas života konkrétneho jedinca.

Predkladaný príspevok rozširuje nie velkú databázu zvieracej paleopatológie, demonštruje dlhú históriu poškodení skeletu zvierat a, v konkrétnych prípadoch, dokumentuje aj negatívne pôsobenie človeka na zdravotný stav zvierat ním využívaných.

\section{References}

BAKER, JR, BROTHWELL, DR 1980: Animal Diseases in Archaeology. Academic Press, London, 235 p.

BARTOSIEWICZ, L, VAN NEER, W, LENTACKER, A 1997: Draught Cattle: their osteological identification and history. Musée Royal de L'Afrique Centrale, Tervuren, 147 p.

FABIŠ, M 2002: Animal skeletal remains of the LaTène period at the Castle Hill in Nitra. Agriculture (Polnohospodárstvo) 48: 435-443

KATKIN, S 1995: Záchranný výskum v Nitre-Malom seminári. Archeologické výskumy a nálezy na Slovensku v r. 1993, SAV, Nitra, pp. 77-78

MALTBY, M 1979: Faunal studies on urban sites. The animal bones from Exeter 1971-1975. Exeter Archaeological Reports. H. Charlesworth, Huddersfield, $221 \mathrm{p}$.

MILES, AEW, GRIGSON, C 1990: Colyer's Variations and diseases of the teeth of animals. Revised ed., University Press, Cambridge, $672 \mathrm{p}$.

ŠUTTA, J, ORSÁG, A, JANDA, J, KOTTMAN, J, KRÁL, E, NECHVÁTAL, M, ROZTOČIL, V 1986: Veterinárna chirurgia. 2. prepracované a doplnené vydanie, Príroda, Bratislava, $728 \mathrm{p}$.

ZENDULKA, M, ŠKARDA, R, ČERNÝ, L, GROCH, L, HALOUZKA, R, HOLMAN, J, KAMAN, J, KONRÁD, J, MARCANÍK, J, PAUER, T, PIVNÍK, L 1987: Patologická anatomie hospodářských zviřat. SZN, Praha, $688 \mathrm{p}$. 
Plate X

Fabiš M.: Palaeopathology ... pp. 55-58

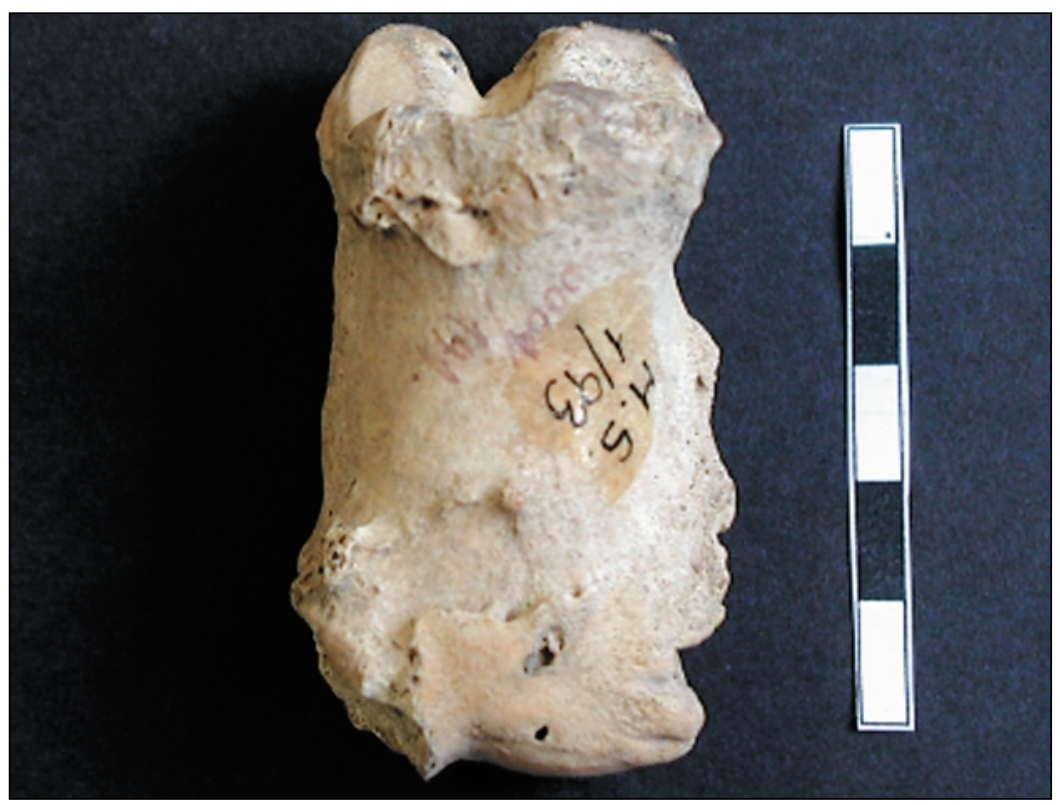

Fig.1. Cattle phalanx proximalis. Exostoses and alterations on proximal and distal articular surfaces. Scale bar $=5 \mathrm{~cm}$.

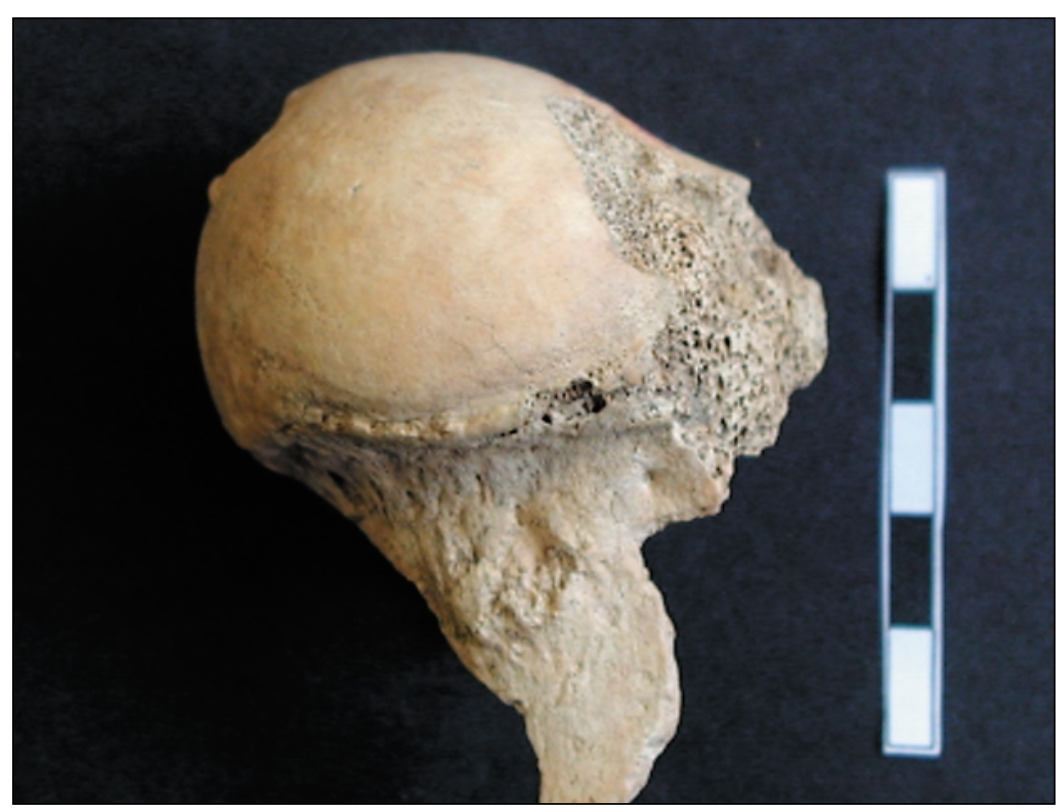

Fig.2. Cattle caput femoris. Exostoses on the edge of the articular surface. Scale bar $=5 \mathrm{~cm}$. 
Plate XI

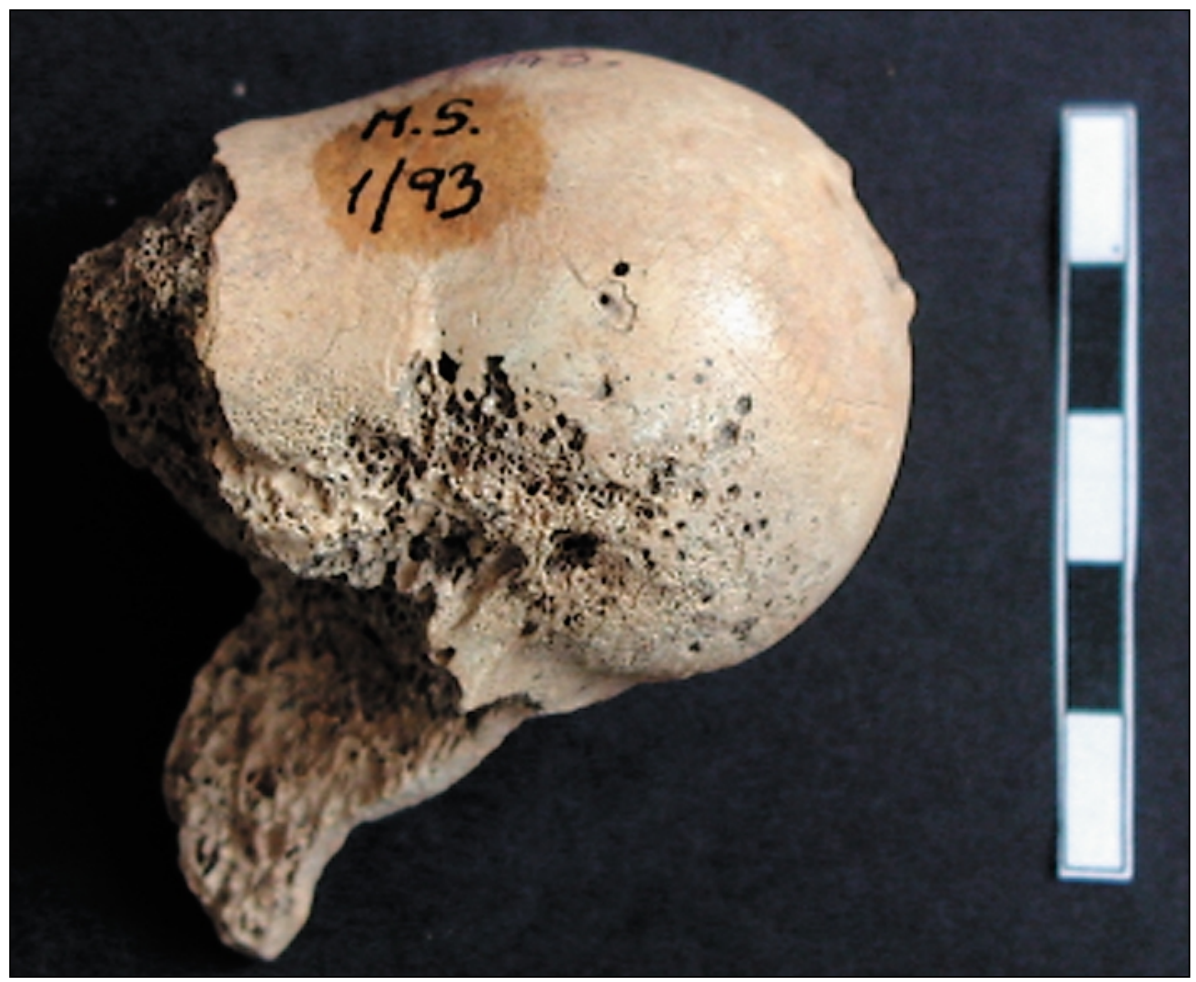

Fig. 3. Cattle caput femoris. Damage of the subchondral bone. Scale bar $=5 \mathrm{~cm}$.

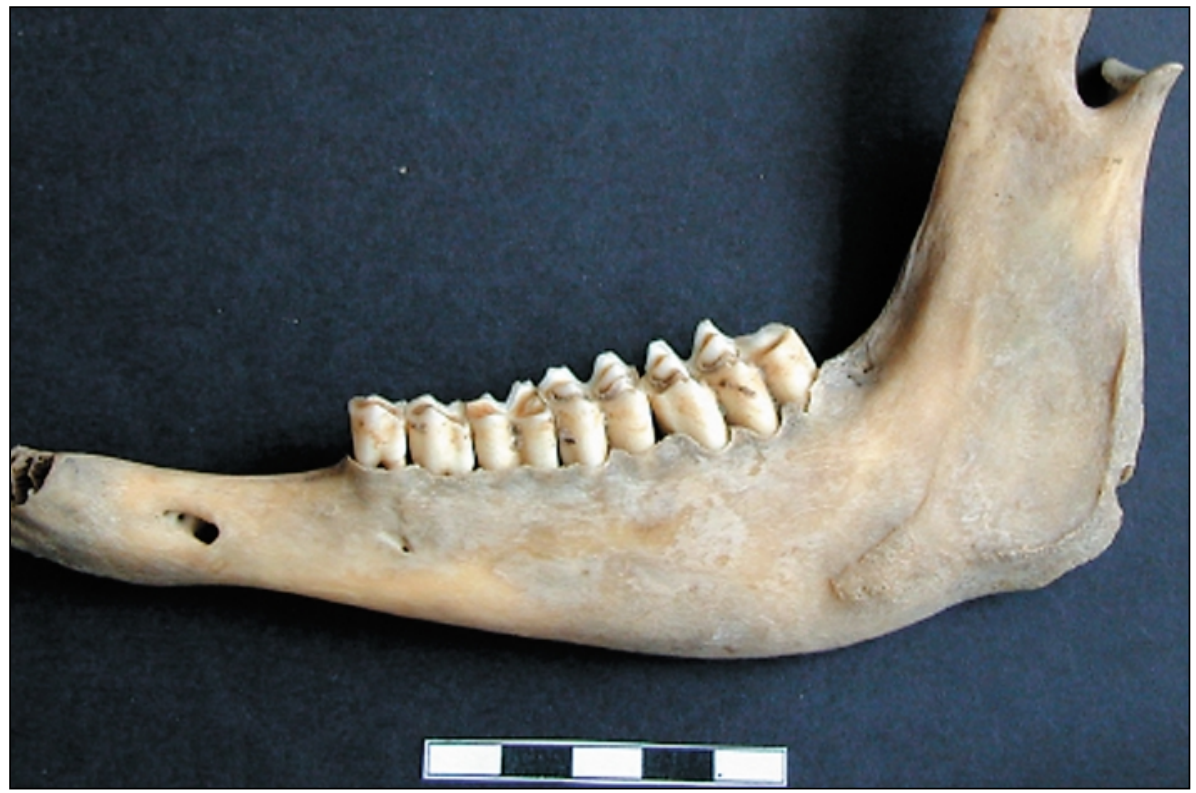

Fig. 4. Sheep mandibula. Absence of the P2. Scale bar $=5 \mathrm{~cm}$. 


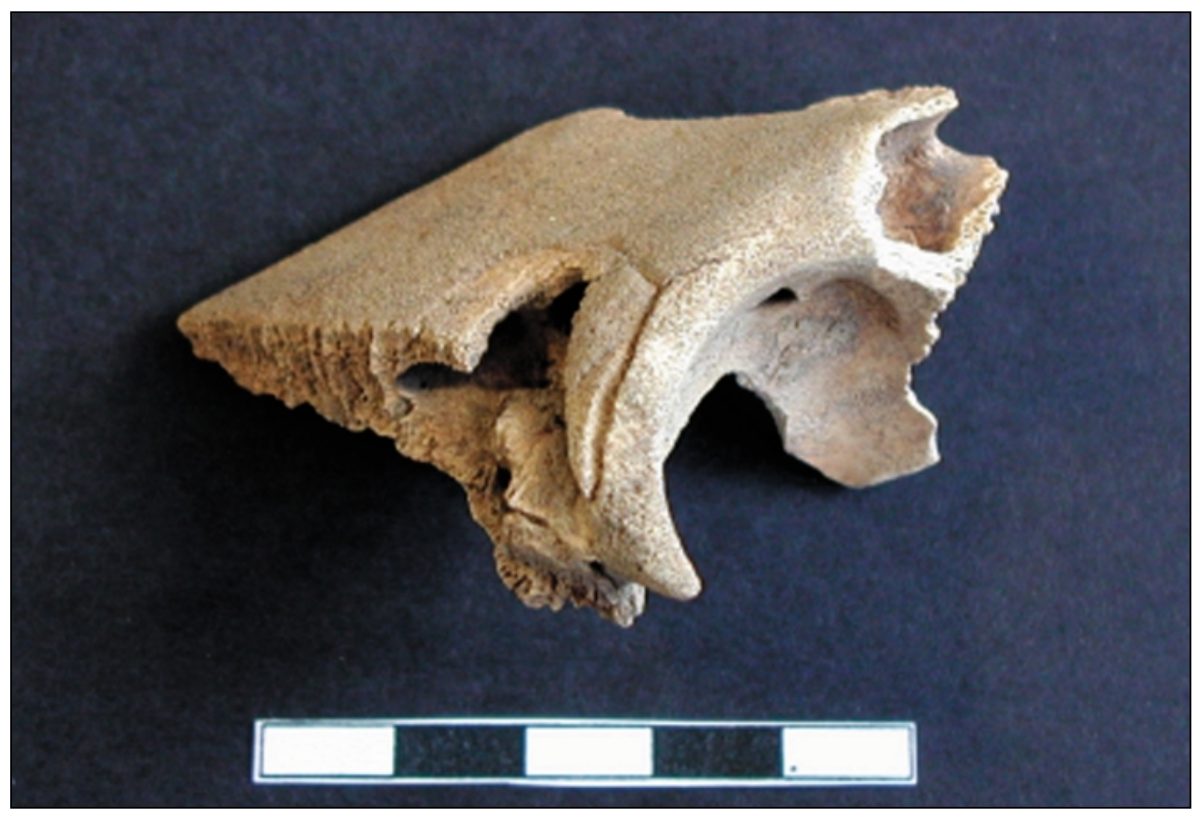

Fig. 5. Pig frontal bone. Impressio of the lamina externa ossis frontalis. Scale bar $=5 \mathrm{~cm}$.

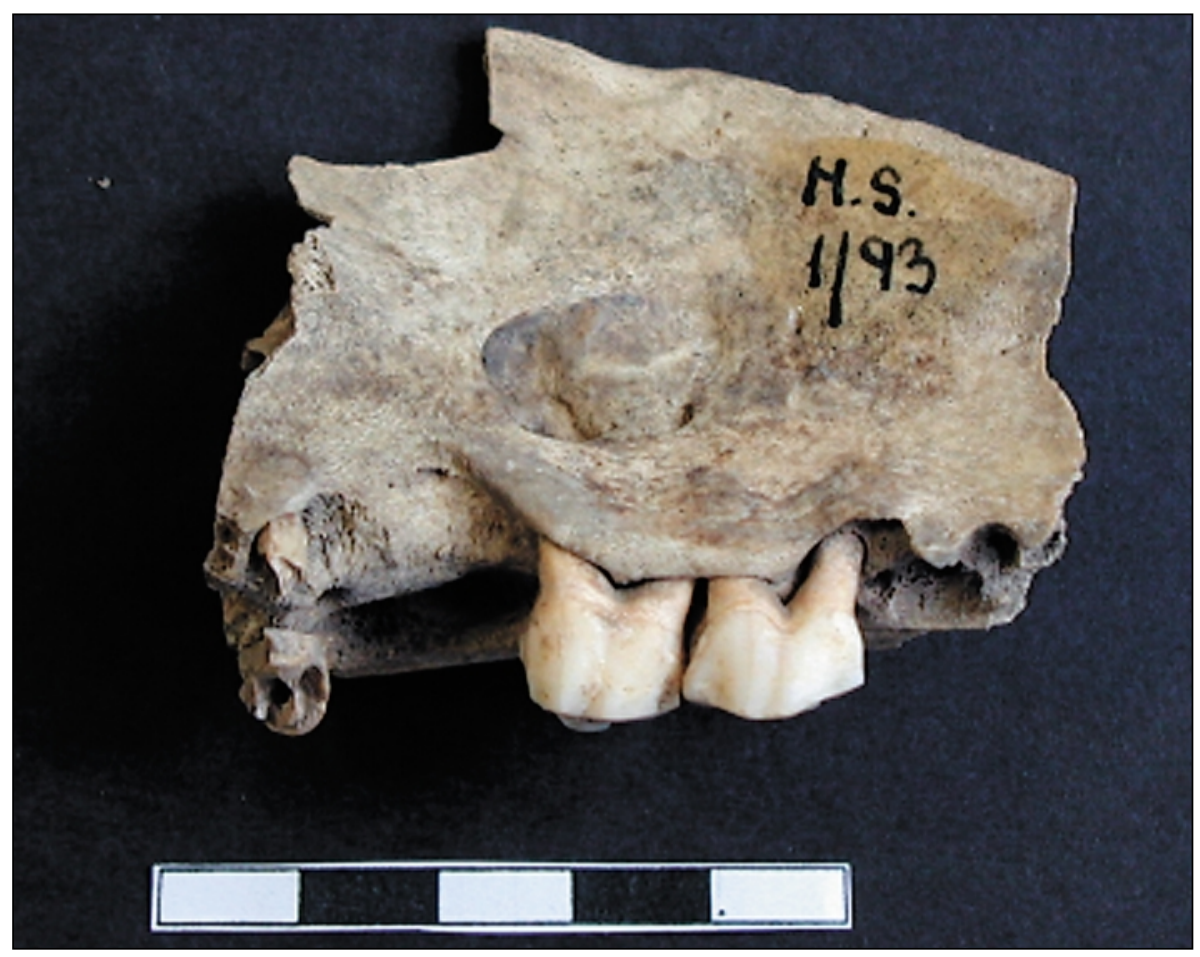

Fig. 6. Pig maxilla. Break out of the M1 and lateral wall of the alveolus. Scale bar $=5 \mathrm{~cm}$. 